\title{
The Effects of Institutional Distance on Foreign-Owned Subsidiary Development: The Case of the Northwest of England
}

\author{
Sven Dahms ${ }^{1}$ \\ ${ }^{1}$ Manchester Metropolitan University Business School, Manchester Metropolitan University, United Kingdom \\ Correspondence: Sven Dahms, All Saints Campus, Oxford Road, Manchester, M15 6BH, United Kingdom. Tel: \\ 97-152-678-7506. E-mail: svendahms@hotmail.com
}

Received: January 19, 2014

Accepted: February 8, 2014

Online Published: February 21, 2014

doi:10.5539/ijbm.v9n3p27

URL: http://dx.doi.org/10.5539/ijbm.v9n3p27

\begin{abstract}
The purpose of this paper is to analyse the effects of institutional distance on foreign-owned subsidiary development. In particular, a distinction between direct and indirect effects of formal and informal institutional distance is proposed and empirically tested. Based on a bespoke census database of all known foreign-owned subsidiaries in the Northwest of England a postal survey has been conducted. The results indicate that informal institutional distance does have a pronounced negative effect on the level of intra- and inter-organisational relationships and decision-making autonomy in foreign-owned subsidiaries. The direct effect of formal institutional distance seems to be less relevant, however, it is becoming significant when the interaction between formal and informal institutional distance is considered. The specific contribution of this study lies in the systematic and comprehensive investigation of the formal and informal institutional distance between home and host country and their effects on subsidiary development. It is one of the first studies to provide a theoretically sound investigation, based on new institutional economics and internalisation theory, of the interaction between formal and informal institutional distance in the context of foreign-owned subsidiaries.
\end{abstract}

Keywords: foreign-owned subsidiaries, institutional distance, Northwest of England, new institutional economics, subsidiary development

\section{Introduction}

Institutions have recently provoked renewed interest from numerous scholars in international business research (Henisz \& Swaminathan, 2008). Withstanding the trends of globalisation, economic integration and advances in technology, institutions are still seen as country specific and persistent (Ghemawat, 2001; Buckley \& Ghauri, 2004, Rugman, 2012), and therefore signify an important factor in attempts to explain the multinational enterprise (MNE) and subsidiary strategy. In particular, the institutional distance between home and host country plays a role (Verbeke \& Yuan, 2005). Interestingly, while there has been considerable effort to explain the effects of institutional distance entry mode decisions (Schwens et al., 2011), much less research has been done at the subsidiary development level (Gaur et al., 2007; Salomon \& Wu, 2012). Indeed, most studies completely neglect institutional differences in the subsidiary development literature (e.g. Forsgren et al., 2005). This study attempts to contribute to the understanding of how institutional distance affects the development of foreign-owned subsidiaries. Subsidiaries are important in that context for three main reasons: Firstly, subsidiaries play an essential role for the MNE as a whole, in terms of learning, innovation, knowledge sharing and performance (Rugman \& Verbeke, 2001; Schmid \& Schurig, 2003; Forsgren et al., 2005; Ambos \& Ambos, 2009). Secondly, the subsidiary itself has been found to be a valuable entity in regional development, in terms of performance, knowledge exchange, or increased employment in the host region (Williams, 2003; Dimitratos et al., 2009). Thirdly, due to their location, they are by definition exposed to an institutional setting that differs from that which prevails in the home country of the MNE (Yamin, 2004). This makes the foreign-owned subsidiary an ideal unit of analysis.

This study applies as an institutional perspective in international business (Peng et al., 2008), the new institutional economics (henceforth NIE). NIE is seen as appropriate for investigating a wide range of subsidiaries from various institutional backgrounds, since it is less focussed on single organisations than is the neo-institutional perspective (Kraatz \& Zajac, 1996). Secondly, it is more normative and less descriptive than the macro-institutional approach (Lane, 1997).

Following North (1990), a distinction is emphasised in this study between formal and informal institutions. Formal institutions consist of political rules, legal rules and contracts, and economic rules. Informal institutions consist of customs, language, beliefs, habits, and norms (North, 1990; Henisz \& Williamson, 1999). 
Accordingly, this study assumes that differing institutional environments between countries lead to transaction cost differentials for businesses that conduct cross border transactions (North, 1990; Henisz \& Williamson, 1999). Transaction cost differentials mean the differing costs of transactions relating to certain business exchanges and activities in different countries, which ultimately also affect the cost of production. MNEs operate across country borders and therefore institutional borders, thus they are simultaneously exposed to differing transaction cost settings. This has been linked to institutional arbitrage strategies in MNEs. The concept of institutional arbitrage states that certain firm-specific advantages can be more effectively exploited in certain institutional and economic conditions (Rugman \& Verbeke, 2001). In order to best capture such transaction cost differentials between countries; this study employs the concept of institutional distance.

The concept of institutional distance has found numerous applications in empirical research across the international business literature (Slangen \& Beugelsdijk, 2010; Schwens et al., 2011; Salomon \& Wu, 2012), and is an established part in transaction cost economics research, therein often utilised as a proxy for informal institutional distance, that is uncertainty caused by differing habits, values or norms (Zaheer et al., 2012). Ghemawat (2001) has reinforced the general importance of distance in an international business context in his seminal article. The author argues that distance between countries still matters, even in times of globalisation. This study takes the concept of institutional distance as its focus. The institutional distance concept allows a comparison of countries in a numerical form, enabling the use of statistical methods in the subsequent analysis. The concept is not without shortcomings (c.f. Shenkar, 2001; Berry et al., 2010; Zaheer et al., 2012); however, it is seen here as the best available means to gain broad insights into the relevance of institutional differences between countries where the development of foreign-owned subsidiaries is concerned.

The main objective of this research is to understand the effects of institutional distance between home and host country on subsidiary development. Slangen and Beugelsdijk (2010) suggest that for that purpose, subsidiary level data might be useful to further understand the effects of institutional distance in that context. This study therefore utilises survey data from a census database of foreign-owned manufacturing sector subsidiaries located in the Northwest of England, in order to narrow the stated gap in the current subsidiary development literature. In particular, the overall aim of this article is to further understanding on what effects formal and informal institutional distances have on the development of organisational network relationships and autonomy of the subsidiary.

Networks and autonomy are key concepts in the subsidiary development literature. The network relationships that the subsidiary has with business and non-business actors within and outside the multinational network has been linked to increased performance, knowledge flows and regional development among others (Bartlett \& Ghoshal, 1989; Rugman \& Verbeke, 2001; Schmid \& Schurig, 2003; Forsgren et al., 2005; Ambos \& Ambos, 2009). The concepts of decision making autonomy has been emphasised in particular after the shift away in the literature from more headquarter centred perspectives towards the focus on subsidiaries and their individual contribution (Edwards et al., 2002; Verbeke \& Yuan, 2005).

This research thereby also follows Zaheer et al.'s (2012) call that the distance concept should be used in a more narrowly defined way. It also follows various calls in the related literature for more empirical research on NIE (Williamson, 2000). Finally, given that transaction cost economics can be seen as apart of the new institutional economics, this research also follows Rugman \& Verbeke (2003) call for the application of TCE in non-entry-mode international business research.

Furthermore, this study investigates the interaction effect of formal and informal institutional distance on subsidiary development. This is one of the first studies to test and interpret such an interaction effect. This article is structured as follows: Sections 2.1 to 2.4 develops the hypotheses. Section 3 discusses the method and data collection. Section 4 presents the results of the analysis, the last section concludes this article with a concise discussion of the results, conclusion, implications and limitations.

\section{Literature Review and Hypothesis Development}

\subsection{Institutional Distance and Intra-Organisational Relationships}

\subsubsection{Formal Institutional Distance and Intra-Organisational Relationships}

Formal institutional transaction cost differentials between home and host country are seen in this study as creating opportunities for institutional arbitrage. Formal institutional distance has therefore not only the more commonly emphasised frictional effects (e.g., Slangen \& Beugelsdijk, 2010; Schwens et al., 2011), but also enabling ones (Rugman \& Verbeke, 2001). The enabling effect of formal institutions is, in particular, expected to play a role for subsidiaries located in developed countries. This is because certain frictional risks, such as expropriation, are relatively lower in these countries (Berry et al., 2010). Even though developed countries appear similar in many ways (e.g. in regard to intellectual property rights protection), differences in the types of economic, political, and legal systems remain prevalent, which provides the basis for transaction cost 
differentials between countries (North, 1990; Rugman \& Verbeke, 2001; Buckley \& Ghauri, 2004). The relevant sources of differing transaction costs include, for example, governmental technological and fiscal policies, bureaucratic efficiency, labour market flexibility, legal traditions, and location-specific knowledge. Hence, a host country can provide a beneficial formal institutional setting, in which value adding activities can be located in order to minimise the transaction costs for the MNE, as well as to create new (or to internally transfer existing) firm-specific advantages (henceforth FSAs) (Rugman \& Verbeke, 2001). MNEs are expected to adapt their internal organisational structures accordingly so as to internalise market 'imperfections', with the intention of taking full advantage of them (Rugman, 2012). In order to fully exploit potential formal transaction cost differentials, the MNE and the subsidiary are expected to develop higher levels of intra-organisational network relationships. This position emphasises the important role a subsidiary can play in the 'endogenisation' of location-specific advantages (Rugman \& Verbeke, 2001, p. 239).

Rugman \& Verbeke (2001) emphasise further that, although the subsidiary can also create FSAs through its own initiative, the links to the headquarters, as well as to other units within the MNE network, often play a contributory role in the process. Furthermore, higher levels of intra-organisational relationships can also facilitate the transfer of products, knowledge and technology between the subsidiaries and the head quarters (Monteiro et al., 2008). Greater transaction cost differentials between home and host country can therefore increase the importance of those subsidiaries located in countries at a greater formal institutional distance.

Empirical studies show support for the claim that FSA creation and transfer can be more efficiently facilitated through higher levels of intra-organisational relationships (e.g., Birkinshaw et al., 1998; Schmid \& Schurig, 2003; Forsgren et al., 2005). This group of studies, however, neglects the link to institutions and, in particular, gradual formal institutional differences between home and host country. Hence, the following hypothesis will be tested.

Hypothesis 1: Greater formal institutional distance is positively associated with higher levels of intra-organisational relationships.

\subsubsection{Informal Institutional Distance and Intra-Organisational Relationships}

MNEs seem to show an increased propensity to internationally disperse and specialise in value-adding activities throughout their networks (Rugman \& Verbeke, 2001; Buckley \& Ghauri, 2004). This can lead to a more fine-tuned interdependency between the subsidiary, other affiliates and the headquarters, which is due to the complementary nature of the production assets in the MNE's network. However, this makes it somewhat less efficient to integrate local variation in the network, concerning for instance technological standards or processes, as this would impede the internal exploitation of economies of scale and scope (Rugman \& Verbeke, 2001). Subsequently occurring higher hierarchical costs for the MNEs, are expected to be overcome by internalising those imperfections through the internal MNE network (Buckley \& Casson, 1976). Local variations in habits, norms and values can hence increase the costs of transaction for the MNE (Henisz \& Williamson, 1999). Additionally, subsidiaries located in countries at a greater informal institutional distance could be more likely to require transfers of technology and knowledge, especially if technology and managerial capabilities are part of the FSAs, in order to achieve the necessary productivity and quality levels to match the rest of the MNE and further increase costs of transaction (Ambos \& Ambos, 2009; Buckley, 2009).

Hence, the subsidiary is expected to rely on a wide range of inputs, not only from the headquarters, but also from other affiliated units within the MNE network. This potentially reciprocal transfer is unlikely to contribute to the development of lasting focal relationships between the subsidiary and other affiliates (Hennart, 1991). Hence, the following hypothesis will be tested.

Hypothesis 2: Greater informal institutional distance is negatively associated with higher levels of intra-organisational relationships.

\subsection{Institutional Distance and Inter-Organisational Relationships}

\subsubsection{Formal Institutional Distance and Inter-Organisational Relationships}

The increasing importance of subsidiaries located abroad for the creation and dissipation of FSAs is well documented in the literature (c.f. Dunning \& Lundan, 2008). Especially emphasised in the MNE network studies has been the factor of access to local networks through the subsidiary (Rugman \& Verbeke, 2001). However, most studies argue from an industry, local-clusters, or corporate point of view, but neglect the institutional perspective and transaction cost differentials between home and host countries (e.g. Birkinshaw et al., 1998; Forsgren et al., 2005). The institutional friction literature neglects such external relationships since they are seen as threats to the MNE, for example because of a lack of property rights protection or inefficient contract enforcement mechanisms in countries at a greater formal institutional distance (Henisz \& Williamson, 1999; Feinberg \& Gupta, 2009; Slangen \& Beugelsdijk, 2010). 
This study aims to bridge the gap between these two streams of literature, that is external networks and institutions in a foreign-owned subsidiary context. The formal institutional setting in a host location can offer comparatively lower transaction and contracting costs for the subsidiary when dealing with external business entities. For example through more efficient contract enforcement mechanisms, fiscal policy, market regulation policy, access to existing collaborative projects between industry and local science centres, or government projects (Rugman \& Verbeke, 2001). Hence, greater formal institutional distance can be seen as a facilitating factor for the development of links with external business entities. In particular, if these transaction cost differentials can be internalised by the MNE, by allocating specific activities and tasks to subsidiaries. This seems especially prevalent, given the trend of knowledge and innovation sourcing in such subsidiaries rather than more traditional material sourcing (Dunning \& Lundan, 2008). Domestic business and non-business entities located in such countries may have developed unique competencies or technologies that are comparatively difficult for the MNE to develop, or access, in its home country (Rugman \& Verbeke, 2001). Hence, it has been argued that cooperation with local business and non-business entities can broaden the range of options for accessing local tacit knowledge (Forsgren et al., 2005). Therefore, the following hypothesis is to be tested:

Hypothesis 3: Greater formal institutional distance is positively associated with higher levels of inter-organisational relationships.

\subsubsection{Informal Institutional Distance and Inter-Organisational Relationships}

Differences in customs, language, beliefs, and habits are important and persistent obstacles to the development of higher levels of inter-organisational relationships by the subsidiary (Gatignon \& Anderson, 1988; Henisz \& Williamson, 1999). Unfamiliarity, information asymmetries, and the liability of foreignness are seen as the main drivers of these additional costs (Buckley \& Casson, 1976; Henisz \& Williamson, 1999; Verbeke \& Greidanus, 2009). An internal obstacle to the development of inter-organisational relationships can be the higher costs for the headquarters of monitoring such external relationships. Unfamiliarity has also been identified as a factor leading to more risk-averse, and hence less cooperative, behaviour on the part of subsidiaries located in countries at a greater informal institutional distance (Gatignon \& Anderson, 1988; Caves, 2007). Therefore, transactions with external entities are more likely to be market-based in nature, rather than long-term collaborations. This means, from an internalisation theory point of view, that MNEs from countries at a greater informal institutional distance will primarily exploit their own FSAs. Hence, the following hypothesis is to be tested:

Hypothesis 4: Greater informal institutional distance is negatively associated with higher levels of inter-organisational relationships.

\subsection{Institutional Distance and Decision-Making Autonomy}

\subsubsection{Formal Institutional Distance and The Subsidiary’s Strategic Decision-Making Autonomy}

Strategic decisions with regard to a change of product range or the launch of a new product can be strongly affected by the formal institutional setting in the host country. In the vertical direction, the implementation of new production processes or certain $\mathrm{R} \& \mathrm{D}$ activities have to be aligned to local regulations, resulting in varying degrees of efficiency across formal institutional settings (Slangen \& Beugelsdijk, 2010). The subsidiary is likely to possess more specific and accurate knowledge about the local regulatory environment than does the headquarters (Roth \& O'Donnell, 1996). It is therefore argued that such strategic decisions are more efficiently made at the subsidiary level, rather than by the headquarters, as this will maximise the expected returns from the investment, minimise the risk associated with it and, most importantly, take advantage of transaction cost differentials (Verbeke \& Yuan, 2005).

Furthermore, subsidiaries located in developed countries tend to be more specialised and carry out more complex tasks and activities (Gaur et al., 2007). Previous studies indicated that, with increasing task complexity, the level of autonomy increases as well (Edwards et al., 2002; Verbeke \& Yuan, 2005). Based on such expectations, the following hypothesis is to be tested:

Hypothesis 5: Greater formal institutional distance is positively associated with higher levels of subsidiary strategic autonomy.

\subsubsection{Informal Institutional Distance and The Subsidiary's Decision-Making Autonomy}

In NIE and the wider international business literature, it is argued that, with greater informal institutional distance, the cost of information, the unfamiliarity with the host location, and the difficulties of transferring FSAs are all greater as well (Buckley \& Casson, 1976; Gatignon \& Anderson, 1988; Rugman \& Verbeke, 2001). However, the resulting degree of control is far from agreed upon. One argument suggests that, in order to reduce these costs, the level of control over the subsidiary has to be reduced (Gatignon \& Anderson, 1988; Henisz \& Williamson, 1999). This is often based on the proposition that, if information is difficult to obtain or interpret, it 
is more efficient to minimise the level of control in order to reduce information costs and the risk of making unfavourable decisions. The contrary argument is that these costs are minimised through exercising higher levels of control (Hennart, 1991).

That is, in order to ensure that the subsidiary's strategic goals comply with those of the headquarters, the degree of decision-making autonomy is reduced. It is argued in this study that the former argument seems more valid with regard to formal institutional cost differentials, but is less likely to apply with regard to informal institutional cost differentials.

Informal institutional distance is seen as unlikely to provide an enabling institutional factor that will minimise the anticipated costs of transactions, due to an observed increased interdependencies of MNE networks (Forsgren, 2004; Buckley \& Ghauri, 2004), and an observed tendency of MNEs to transfer FSAs between locations, which in turn can necessitate more centralised decision making (Henisz \& Williamson, 1999). Hence, the following hypothesis is to be tested.

Hypothesis 6: Greater informal institutional distance is negatively associated with higher levels of subsidiary strategic autonomy.

\subsection{Interaction Terms}

The effects of formal and informal institutional distance on subsidiary development have been tested to some extent in the discussed literature. The last set of hypotheses in this study proposes an additional interaction effect of formal and informal institutional distance on subsidiary development. Testing for interaction effects of formal and informal institutions on multinational strategy, has been called for in the literature (e.g. Peng \& Pleggenkuhle-Miles, 2009; Rugman et al., 2011). In this study, the topic is explored in the context of the strategic development of foreign-owned subsidiaries. This study takes as a starting point for the theoretical argument the work of North (1990). North argues that formal and informal institutional settings in a country have an inherently asymmetric constellation (ibid.). This can be caused by institutional path-dependency. Institutional path-dependency means that existing institutional settings are not necessarily the most efficient ones, but evolve according to their own dynamic (North, 1990; Williamson, 2000). This indicates that there might be potential tensions between formal and informal institutional settings in countries. Those can be important for MNEs given that the institutional setting as a whole is relevant for the strategic development of subsidiaries in host countries (Yamin, 2004; Rugman et al., 2011). Accordingly, the present study argues that the interaction between formal and informal institutional distance also affects the strategic development of foreign-owned subsidiaries.

For example, informal institutional differences between actors can raise transaction costs, through the ways negotiations are held, or differing expectations between two parties (North, 1990). The moderating effect of informal institutional distance on formal institutional distance is therefore likely to affect the levels of inter-organisational and intra-organisational relationships of the subsidiary. In particular, it is expected that potential gains made through allocating certain value-adding activities according to the formal institutional setting of the host country could be offset by additional costs due to structural market imperfections caused by informal institutional distance. It is hence plausible that there could be a systematic difference in the integration into local networks and integration into the MNE networks, of those subsidiaries located in countries that are simultaneously at a greater informal and formal institutional distance (Yamin, 2004; Rugman et al., 2011). Similarly develops the argument for the interaction term and autonomy of the subsidiary.

It is also expected that informal institutional distance moderates potential positive effects of formal institutional distance on subsidiaries' decision-making autonomy. The additional costs, caused by unfamiliarity with informal institutions, could impede the level of autonomy granted to the subsidiary. Therefore, the headquarters might exert a higher level of control over subsidiaries located in countries at a greater informal and formal institutional distance (Henisz \& Williamson, 1999; Gaur \& Lu, 2007). Accordingly, the potential gains to be made through granting higher levels of autonomy to subsidiaries located in formally institutionally distant countries, could be sacrificed by the MNE in order to minimise the increased transaction costs caused by greater informal institutional distance.

Therefore, the following exploratory hypotheses are putforward:

Hypothesis 7a: The interaction between formal and informal institutional distance will be negatively associated with the level of intra-organisational relationships.

Hypothesis $7 \mathrm{~b}$ : The interaction between formal and informal institutional distance will be negatively associated with the level of inter-organisational relationships.

Hypothesis 7c: The interaction between formal and informal institutional distance will be negatively associated with strategic decision-making autonomy. 
The following figure summarises the conceptual framework, which will be tested statistically.

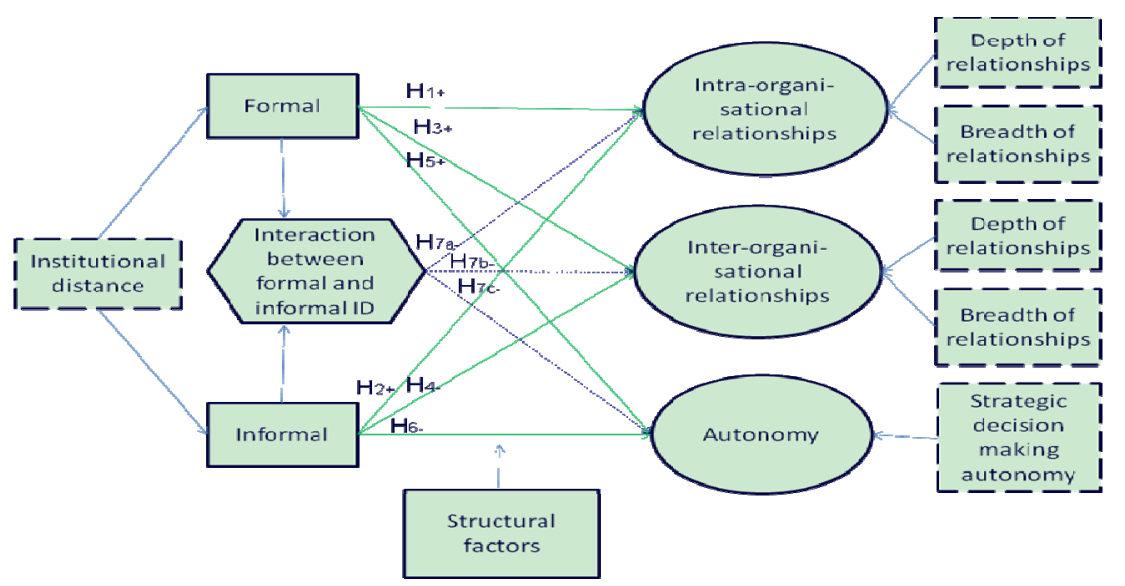

Figure 1. Conceptual framework of this study

\section{Data and Methods}

This research utilises a postal survey design. This seems most appropriate to fulfil the aim and objectives of the research, for the following reasons: Firstly, previous studies often use secondary data, which provide valuable insights into the macro-level effects of institutional differences (e.g., Gaur \& Lu, 2007; Slangen \& Beugelsdijk, 2010), however; those fall short of providing necessary details on organisational relationships of the subsidiary. Secondly, this study can fall back on a census database of foreign-owned subsidiaries. This means that shortcomings of previous survey based studies, such as the focus on a limited number of home countries (Taggart \& Hood, 1999; Gaur \& Lu, 2007; McDonald et al., 2008), and potential non-coverage bias (Dillman, 2000; Yang et al., 2006) can be reduced.

Given that this study aims to include a wide range of subsidiaries, their sheer number makes in-person interviews unfeasible. Furthermore, the concepts that are of interest are relatively well established in the international business survey literature. This means that they can be formulated as closed-ended questions, which also brings the advantage of enabling subsequent statistical analysis. Postal surveys are not without shortcomings. For example, some surveys suffer from common method bias. However, this risk is reduced in this study, given that the most important explanatory variables are developed from secondary data rather than from the same respondent (Chang et al., 2010).

\subsection{Sample and Data Collection}

The data used in this research are based on a census database which covers all manufacturing foreign-owned subsidiaries in the Northwest of England. A bespoke database has been created. It provides the largest and most comprehensive, up-to-date data of foreign-owned subsidiaries known to the author. The database has been developed from EXPERIAN business directories, FAME and Dun and Bradstreet. The merger of those databases, double entry procedures and subsequent data cleaning has led to a most complete census of all known foreign-owned subsidiaries in the region. The contact details were verified directly through phone calls to each subsidiary, as well as through exhaustive internet searches. The result is a census of 827 foreign-owned manufacturing sector subsidiaries. This study takes the site of operations as the unit of analysis. That is, it goes beyond larger subsidiaries that can be responsible for various sites in a certain area. This has the advantage of maximising the likely hood of having reliable responses, given that site managers can be expected to be much more familiar with their interaction with local external networks than the managers of establishments or headquarters (Osterman, 1994; Forsgren et al., 2005). Some amendments had to be made for this study. The following were removed from the dataset: sites owned by holding companies, non-active trading sites, wrong addresses, changes of ownership, as well as sites that refused to participate. This reduced the sampling frame to 456 foreign-owned subsidiaries from 28 different nations.

A self-administered questionnaire was sent to the managing director of each subsidiary in the sampling frame. Both the design of the questionnaire, and its postal administration, has closely followed Dillman's (2000) tailored design method. The questionnaire was discussed with a panel of academics and practitioners, and afterwards piloted in five one-on-one assessment sessions with managing directors of subsidiaries from different home countries and industries. Subsequently, minor changes were made before the final version of the questionnaire was sent out. The questionnaire was sent out in three waves, allowing the respondents four weeks 
to answer the questionnaire. Three weeks after the last wave, the non-respondents were reminded via telephone calls. Finally, the study was left with 108 usable responses, which equates to a response rate of $23.7 \%$. Contributing towards this study's aim and objective, the respondents come from 26 different home countries from mostly developed backgrounds and cover a heterogeneous range of industries. Sample representativeness has been assured through chi-square tests using home region (European and non-European home country) and industry (high or low technology sector). Furthermore, wave analysis was conducted in order to identify response bias. The tested categories were the size of the subsidiary, home region and industry. No response bias was found.

\subsection{Operationalisation and Measurement of the Variables}

Subsidiary organisational relationships: This variable measures the nature of how the subsidiary transacts through its networks. The internal and external network transactions are measured along two dimension (Dimitratos et al., 2009): intensity (i.e. the frequency of contacts with other entities) and extensity (i.e. the number of entities with which the subsidiary has a relationship). The respondents were asked to indicate on seven-point Likert scales, their number of relationships, ranging from none (1) to many(7), and the frequency of their relationships, ranging from low (1) to high (7).

Inter-organisational relationships (Inter-Org) (Cronbach alpha: 0.830) included 'local customers', 'local suppliers', 'local competitors', 'regional governmental institutions', and 'regional science centres and universities'. The categories were adapted from Frost et al. (2002) and Schmid \& Schurig (2003).

Intra-organisational relationships (Intra-Org) (Cronbach alpha: 0.874) included 'buyers','suppliers', 'R\&D and innovation centres', 'headquarters' and 'other units within the MNE organisation'. The categories were adapted from Birkinshaw et al. (1998) and Schmid and Schurig (2003).

Autonomy (Autonomy): This study followed Taggart and Hood (1999), in which strategic decision-making autonomy was operationalised in a dichotomous way that is respondents were asked to indicate whether decisions are made exclusively by the headquarters (1) or exclusively by the subsidiary (7). The decision areas chosen were those considered most relevant for subsidiary development and the strategies of MNEs. Those were adapted from Taggart and Hood (1999) and Edwards et al. (2002) and included the following: 'market area supplied', 'product range', 'R\&D and new product development', 'financial control', 'human resource management', 'producing goods', and 'providing services'.

\subsection{Formal and Informal Institutional Distance}

For the formal institutional distance variable (Formal), this study utilised data from the Global Competitiveness Report, which is published annually by the World Economic Forum (WEF). The data in the report, dating 2010-2011, were collected from an extensive survey of 13,607 business executives from 139 countries, which is an average of 98 responses per country. Selected items were taken from the WEF report.

The measures capture the institutional differences between countries in accordance with North (1990), who suggests investigating formal institutions through policy, legal and economic rules. Similar measures have been used in Gaur and Lu (2007) and Slangen and Beugelsdijk (2010). The indicators are listed in Table 1.

Table 1. Formal institutional indicators

\begin{tabular}{|c|c|c|}
\hline $\begin{array}{l}\text { Formal institutional } \\
\text { pillar }\end{array}$ & institutional & Measurement \\
\hline \multirow{3}{*}{$\begin{array}{l}\text { Heterogeneity between } \\
\text { countries policy }\end{array}$} & $\begin{array}{l}\text { Transparency of } \\
\text { government policy making }\end{array}$ & $\begin{array}{l}\text { How easy is it for businesses in your country to obtain information about changes } \\
\text { in government policies and regulations affecting their activities? }(1=\text { impossible; } 7 \\
=\text { extremely easy) }\end{array}$ \\
\hline & $\begin{array}{l}\text { Burden of government } \\
\text { regulation }\end{array}$ & $\begin{array}{l}\text { How burdensome is it for businesses in your country to comply with governmental } \\
\text { administrative requirements (e.g., permits, regulations, reporting)? ( } 1=\text { extremely } \\
\text { burdensome; } 7 \text { = not burdensome at all) }\end{array}$ \\
\hline & $\begin{array}{l}\text { Effectiveness of } \\
\text { anti-monopoly policy }\end{array}$ & $\begin{array}{l}\text { To what extent does anti-monopoly policy promote competition in your country? }(1 \\
=\text { does not promote competition; } 7=\text { effectively promotes competition) }\end{array}$ \\
\hline Legal rules & $\begin{array}{l}\text { Efficiency of legal } \\
\text { framework in settling } \\
\text { disputes }\end{array}$ & $\begin{array}{l}\text { How efficient is the legal framework in your country for private businesses in } \\
\text { settling disputes? ( } 1=\text { extremely inefficient; } 7=\text { highly efficient })\end{array}$ \\
\hline Economic Rules & $\begin{array}{l}\text { Intensity of local } \\
\text { competition }\end{array}$ & $\begin{array}{l}\text { How would you assess the intensity of competition in the local markets in your } \\
\text { country? }(1=\text { limited in most industries; } 7 \text { = intense in most industries })\end{array}$ \\
\hline
\end{tabular}

Source: WEF Report 2010-2011. 
Informal institutional distance (Informal) is measured based on the World Value Survey (WVS) (Inglehart et al., 2004). The survey provides 99,000 observations from representative samples of the population taken from over 60 countries. Due to its coverage, timeliness, and rigour, the WVS is seen as somewhat preferable to the datasets that are commonly applied in international business studies, such as Hofstede or GLOBE (Zaheer et al., 2012). Similarly to Hofstede and GLOBE the authors of the WVS searched for dimensions within their dataset. Their analysis resulted in the development of two informal institutional dimensions, which explain $70 \%$ of the cross-cultural variance in their study: first, traditional authority vs. secular-rational authority (TSR) and, second, survival values vs. self-expression values (SSE) (Inglehart et al., 2004). The TSR dimension quantifies differences between society's orientation and expectations towards traditional values, on the one hand, and individualism, on the other. The SSE dimension quantifies differences in society's attitudes towards work-life balance. These factors allow a relatively clear distinction to be made between countries' differing informal institutional attitudes (Inglehart \& Welzel, 2010). Each dimension takes values ranging from -2.5 to 2.5. Given the dimension of the survey and the scope of informal institutions, the decision was made to use the aggregated measures from the WVS, as provided by Inglehart et al. (2004). This is seen as appropriate for this research in order to sufficiently approximate informal institutions, and it also follows common practice in empirical research (e.g. Salomon \& Wu, 2012).

Following the main thrust in the international business literature (e.g., Gaur \& Lu, 2007; Slangen \& Beugelsdijk, 2010; Berry, et al., 2010), the distance scores were calculated using the Kogut and Singh formula. In order to ensure a normal distribution, the resulting distance scores were transformed into their natural logarithms.

Control Variables: This study controlled for several factors. The size of the subsidiary was included (Empl). In order to ensure a normal distribution, the scores were transformed into their natural logarithms. Entry mode (Emode) was coded ' 1 ' for green field and ' 0 ' for acquisitions and joint ventures. The industry (Industry) in which the subsidiary operates was coded ' 0 ' for low- and medium-low-technology industries, and ' 1 ' for medium-high- and high-technology industries. This follows the common OECD categorisation. Whether or not the subsidiary is part of a UK multinational headquartered abroad (UK Multi) was also controlled for (if so, they were coded ' 1 ', if not ' 0 '). Furthermore, the relative competence of the subsidiary was controlled for. The following question was asked: "Please indicate the capability or distinctive expertise of your site in the following areas relative to other units in the corporation e.g. headquarters and/or other subsidiaries $(1=$ far below average, $7=$ far above average)." The areas asked about were Sales or Distribution, Ancillary Service Functions, Marketing, Production of Goods or Services, R\&D and New Product Development, and Purchasing. Whereas the first three are traditional activities carried out by foreign-owned subsidiaries, the others have been identified more recently as part of a general upgrade across MNEs in their subsidiaries abroad. The two sets of items were transformed into two variables, Traditional Competences (Trad Comp) (Cronbach alpha $=0.614)$ and Extended Competences (Extend Comp) (Cronbach alpha $=0.600$ ), using the accumulated average scores. This is a formative measure (i.e. the observed variable causes the latent variable); hence, high Cronbach alphas were not expected. Relatively low Cronbach alphas for this measurement are caused when subsidiaries have high competences in one area, but not in others. Nunnally (1978) states that a Cronbach alpha of 0.6 can be sufficient. This level is also seen as acceptable in international business literature when a formative method has been used to create an index (Birkinshaw \& Hood, 2000).

\subsection{Analysis}

This study used ordinary least squares regression to analyse the data. Prior to the regression analysis, various tests were conducted in order to ensure normality, linearity, homogeneity of variance, and to check for potential common method bias. None of the results where alarming, hence stepwise regression was deemed appropriate. The analysis proceeded as follows: First, the control variables were regressed on their own on the three dependent variables, that is, intra-organisational relationships, inter-organisational relationships, and decision-making autonomy (see Regressions 1, 4, and 7 in Table 3).

In the next step, the main explanatory variables, informal institutional distance and formal institutional distance, were added (Regressions 2, 5, and 8). The final regressions included the interaction term between informal and formal institutional distance (Regressions 3, 6, and 9). For the sake of presentation, only the standardised beta coefficients and the t-values are reported in the table2. Since the hypotheses predicted directionality, one-tailed tests were used throughout. 


\section{Results}

Table 2. Descriptive statistics and correlation matrix

\begin{tabular}{|c|c|c|c|c|c|c|c|c|c|c|c|c|c|}
\hline & Mean & S.D. & 1 & 2 & 3 & 4 & 5 & 6 & 7 & 8 & 9 & 10 & 11 \\
\hline 2 Intra-Org & 4.11 & 1.35 & 0.05 & 1 & & & & & & & & & \\
\hline 3 Inter-Org & 3.09 & 1.13 & 0.01 & 0.18 & 1 & & & & & & & & \\
\hline 4 TradComp & 4.63 & 1.29 & 0.11 & 0.07 & $0.19^{*}$ & 1 & & & & & & & \\
\hline 6 Emode & 0.21 & 0.41 & $-0.23^{*}$ & 0.15 & 0.08 & 0.03 & $-0.25 * *$ & 1.00 & & & & & \\
\hline 7 UK Multi & 0.42 & 0.50 & -0.07 & $0.30 * *$ & 0.04 & 0.14 & 0.15 & -0.03 & 1.00 & & & & \\
\hline 8 Industry & 0.53 & 0.50 & -0.08 & 0.13 & $0.21 *$ & 0.12 & 0.00 & -0.01 & $0.23 *$ & 1.00 & & & \\
\hline 11 Formal & -0.72 & 0.97 & 0.06 & 0.11 & -0.08 & 0.09 & 0.02 & 0.05 & 0.03 & -0.09 & -0.07 & 0.07 & 1.00 \\
\hline
\end{tabular}

**. $\mathrm{p}<0.01$ (two-tailed); *. p $<0.05$ (two-tailed).

The correlations between the transformed variables are presented here in order to gain an overview of their bivariate relationships. The correlation matrix shows no extremely high correlations between the variables $(r>0.9)$ (Hair et al., 1998). This also indicates that multicollinearity should not be a major issue in this study.

\subsection{Regressions}

Table 3 shows that all of the regression models are significant. R-square and F values are in line with similar studies in the field (e.g., Yamin \& Andersson, 2011). Tests for potential violations of the OLS regression assumption have been conducted in all the models. No violations have been detected. To detect any multicollinearity problems, variance inflation factors (VIF) have been calculated for each of the regression models. None of the VIFs are higher than 2.6, which is far below the suggested threshold of 10 (Hair et al., 1998). Following Dikova and van Witteloostuijn (2007), an exploratory factor analysis has been conducted with the dependent and control variables collected through the survey. This resulted in an 8-factor solution, with the largest factor explaining only $18.51 \%$ of the variance. This is in line with comparable studies (Dikova \& van Witteloostuijn, 2007) and does not suggest severe problems with common method variance.

The control variable models, that is Regressions 1, 4 and 7, do show results that are in line with the findings of previous studies in the field (c.f., Birkinshaw et al., 1998; Forsgren et al., 2005).

\subsection{Hypothesis Testing}

Regression 2 shows the effects of institutional distance on intra-organisational relationships. Hypothesis 1 predicted a positive relationship between formal institutional distance and the level of intra-organisational relationships. Although the expected positive relationship has been confirmed, it fails to become statistically significant. Hypothesis 2 has been confirmed in this study with significance at the $5 \%$ level.

Regression 5 tested Hypotheses 3 and 4. Hypothesis 3 predicted a positive association between formal institutional distance and inter-organisational relationships. This found no support in this study. The variable failed to reach significance and the coefficients had the opposite sign. The expected negative relationship between informal institutional distance and the level of inter-organisational relationships is confirmed in Regression 5, and reached statistical significance at the 5\% level. 
Table 3. Regression results (standardised beta coefficients are provided, t-values in parentheses)

\begin{tabular}{|c|c|c|c|c|c|c|c|c|c|}
\hline & \multicolumn{9}{|c|}{ Dependent variable: Intra-organisational relationships Dependent variable: Inter-organisational relationships Dependent variable: Autonomy } \\
\hline & Regression 1 & Regression 2 & Regression 3 & Regression 4 & Regression 5 & Regression 6 & Regression 7 & Regression 8 & Regression 9 \\
\hline \multirow{3}{*}{ TradComp } & 0.004 & 0.027 & 0.012 & 0.145 & 0.187 & 0.183 & 0.129 & 0.108 & 0.101 \\
\hline & $(-0.045)$ & -0.281 & -0.132 & $(1.493) \dagger$ & $(1.916)^{*}$ & $(1.863)^{*}$ & $(1.432) \dagger$ & -1.177 & -1.099 \\
\hline & 0.128 & 0.105 & 0.109 & 0.186 & 0.17 & 0.171 & 0.145 & 0.148 & 0.15 \\
\hline \multirow[t]{2}{*}{ ExtendComp } & $(-1.186)$ & -0.979 & -1.045 & $(1.667)^{*}$ & $(1.541) \dagger$ & $(1.548) \dagger$ & $(1.408) \dagger$ & $(1.429) \dagger$ & $(1.454) \dagger$ \\
\hline & 0.201 & 0.212 & 0.218 & 0.12 & 0.141 & 0.143 & -0.15 & -0.162 & -0.158 \\
\hline \multirow[t]{2}{*}{ EMode } & $(2.123)^{*}$ & $(2.249)^{*}$ & $(2.382)^{* * *}$ & -1.232 & $(1.464) \dagger$ & $(1.48) \dagger$ & $(-1.676)^{*}$ & $(-1.78)^{*}$ & $(-1.748)^{*}$ \\
\hline & 0.269 & 0.272 & 0.299 & -0.06 & -0.04 & -0.04 & -0.11 & -0.114 & -0.101 \\
\hline \multirow[t]{2}{*}{ UK Multi } & $(2.818)^{* *}$ & $(2.876)^{* *}$ & $(3.219) * * *$ & $(-0.568)$ & $(-0.452)$ & $(-0.368)$ & $(-1.183)$ & $(-1.252)$ & $(-1.103)$ \\
\hline & 0.072 & 0.075 & 0.047 & 0.202 & 0.184 & 0.175 & -0.05 & -0.035 & -0.05 \\
\hline \multirow[t]{2}{*}{ Industry } & $(-0.759)$ & -0.8 & -0.503 & $(2.077 *)$ & $(1.902)^{*}$ & $(1.795)^{*}$ & $(-0.529)$ & $(-0.387)$ & $(-0.545)$ \\
\hline & 0.103 & 0.144 & 0.108 & 0 & 0.028 & 0.017 & 0.319 & 0.312 & 0.294 \\
\hline \multirow[t]{2}{*}{ Empl } & $(-0.994)$ & $(1.381 \dagger)$ & -1.053 & $(-0.012)$ & -0.258 & -0.156 & $(3.226)^{* * *}$ & $(3.092)^{* *}$ & $(2.893)^{* *}$ \\
\hline & & -0.17 & -0.43 & & -0.19 & -0.27 & & 0.074 & -0.058 \\
\hline \multirow[t]{2}{*}{ Informal } & & $(-1.773)^{*}$ & $(-3.103)^{* *}$ & & $(-1.983)^{*}$ & $(-1.842)^{*}$ & & -0.819 & $(-0.425)$ \\
\hline & & 0.113 & 0.041 & & -0.07 & -0.09 & & 0.075 & 0.04 \\
\hline Formal & & -1.226 & -0.442 & & $(-0.737)$ & $(-0.915)$ & & -0.852 & -0.427 \\
\hline Informalx & & & -0.36 & & & -0.11 & & & -0.182 \\
\hline Formal & & & $(-2.532)^{* * *}$ & & & $(-0.712)$ & & & $(-1.292) \dagger$ \\
\hline $\mathrm{R}$ & 0.395 & 0.438 & 0.492 & 0.329 & 0.385 & 0.391 & 0.485 & 0.497 & 0.509 \\
\hline R-square & 0.156 & 0.192 & 0.242 & 0.108 & 0.148 & 0.153 & 0.235 & 0.247 & 0.259 \\
\hline R-square $\Delta$ & & 0.036 & 0.05 & & 0.04 & 0.004 & & 0.011 & 0.013 \\
\hline F-Value & 3.115 & 2.941 & 3.469 & 2.044 & 2.158 & 1.965 & 5.185 & 4.055 & 3.815 \\
\hline sig. of the model & 0.008 & 0.005 & 0.001 & 0.067 & 0.037 & 0.052 & 0 & 0 & 0 \\
\hline
\end{tabular}

$* * * \mathrm{p}<0.001, * * \mathrm{p}<0.01, * \mathrm{p}<0.05, \dagger \mathrm{p}<0.1$ one-tailed test.

Regression 8 shows the results for Hypotheses 5 and 6 in regard to subsidiaries' decision-making autonomy. Neither relationship was found to be statistically significant. Mixed or non-significant relationships between institutional distance and decision-making autonomy are not unusual in the literature (c.f. Taggart \& Taggart, 2004), lending support to the complexity of the issues surrounding subsidiary decision-making autonomy.

Regression 3 tested the interaction effect of formal and informal institutional distance on the level of intra-organisational relationships. The expected negative association with the interaction term in Hypothesis $7 \mathrm{a}$ has been confirmed. The coefficient had the expected sign and was significant $(p<0.001)$.

Hypothesis 7c predicted a negative relationship between the interaction term and subsidiary decision-making autonomy. This has been confirmed in Regression 9, which shows that the coefficient has the expected sign and is significant at the $10 \%$ level.

Regression 6 shows that no support could be found for the interaction hypothesis $7 \mathrm{~b}$.

Following Jaccard et al. (1990), the interaction term has been further investigated according to the presence, strength and nature in Models 3, 6 and 9. The following table presents the results of the tests.

Table 4. Presence and strength of the interaction effect

\begin{tabular}{llllll}
\hline \multicolumn{2}{l}{ Presence of interaction effect } & \multicolumn{3}{l}{ Strength of the interaction term effect } \\
\hline Model & F-Ratio & t-test (Coefficient) & Model & R-square Change & Variance explained by the interaction term \\
\hline Model 3 & Yes & Yes & Model 3 & 0.05 & $5.0 \%$ \\
Model 6 & NO & NO & Model 6 & 0.004 & $0.4 \%$ \\
Model 9 & NO & Yes & Model 9 & 0.013 & $1.3 \%$ \\
\hline
\end{tabular}

The results for Model 3 show that the proposed interaction effect is present according to F-Ratio changes as well as t-test of the coefficients. In Model 6 such an effect cannot be identified. The interaction effects failed to become significant concerning F-Ratio changes as well as t-test of the coefficients. Model 9 shows evidence for the presence of an interaction effect. Figures 2 and 3 visualise the characteristics of the interaction term in 
Models 3 and 9. For the sake of presentation, the institutional distance values have been categorised as follows: informal institutional reaching from very low to very high; and formal institutions into a dichotomous low and high. The cut-off point was the median.

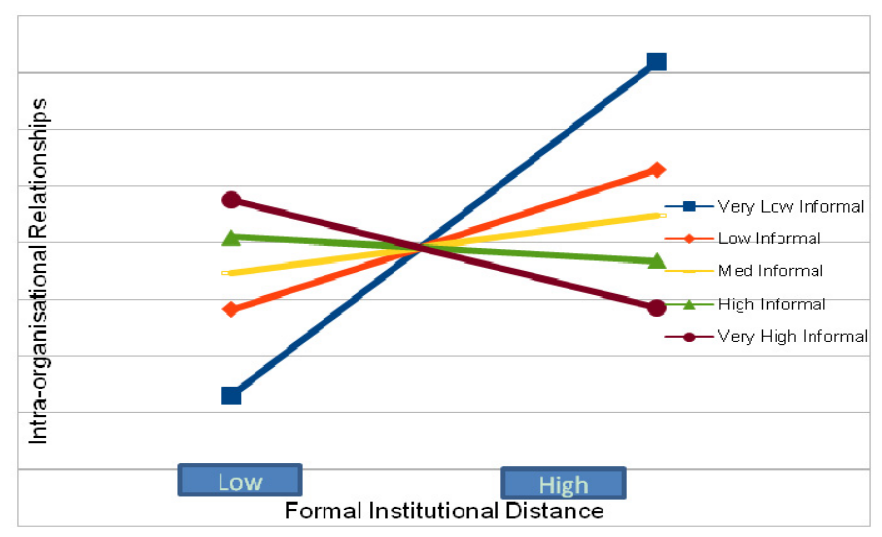

Figure 2. Interaction term model 3

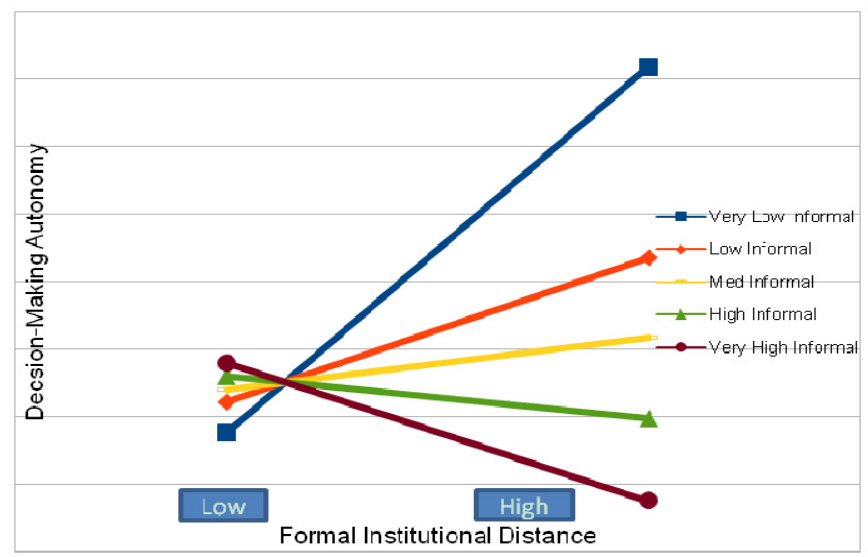

Figure 3. Interaction term model 9

\section{Discussion and Conclusion}

This research aimed at understanding how institutions matter for subsidiary development. Based on a census database of foreign-owned subsidiaries in the Northwest of England, this study systematically and comprehensively investigated the effects of formal and informal institutional distance on subsidiaries' intra- and inter-organisational network relationships as well as their decision-making autonomy. This study contributes three main results to the literature; firstly, formal institutional distance has only a very limited direct enabling effect on subsidiary development. Secondly, informal institutional distance shows a direct negative association with subsidiary network relationships but no association with autonomy. Lastly, the interaction between formal and informal institutional distance is significant for intra-organisational network relationships and autonomy, but not for inter-organisational network relationships.

Concerning the first finding that formal institutional distance seems to have only a very limited direct enabling effect on subsidiary development. It appears that in a relatively stable formal institutional setting such as the UK, the opportunities for institutional arbitrage might be limited at first glance. This finding is in line with literature that investigated institutional differences beyond the extreme comparisons between developing and developed countries such as Frost (2001) using patent citations or Ambos et al. (2006) focussing on knowledge flows. It seems to also support Forsgren et al. (2005) arguments that in such a setting, the subsidiaries internal capabilities are more relevant. However, explicit empirical support for their assertion has not yet been provided in a way as in the present study. This study therefore also adds to the on-going discussion of seeing formal institutions only as hazards and friction. Feinberg and Gupta (2009) and Slangen and Beugelsdijk (2010) found in their large sample studies direct effects of formal institutional risk factors. In this context, by using primary 
survey data from foreign-owned subsidiaries located in a stable institutional environment, such direct associations have not been found. This is also emphasising Berry et al. (2010) who argue that measures of institutional distance are research context dependent and have to be used according to their relevance in order to gain deeper insights into the actual effects of institutions.

The second finding was in line with the expectations of this study, in particular the negative association of informal institutional distance and intra-organisational relationships. Overall, this seems to indicate that subsidiaries located in countries at a greater informal institutional distance tend to be less integrated into the transactional network of the multinational corporation, which is in line with for example Slangen and Beugelsdijk (2010). In a recent conceptual article, Rugman et al. (2011) suggest that the 'compound' distance, i.e. a mixture of spatial, language, informal, and other distances, represent major challenges for MNEs concerning the integration of subsidiaries into their network. However, the authors do not explicate the components of their compound distance argument. The present study adds to this debate, in indicating empirically that informal institutional distance is still a major obstacle to the integration of subsidiaries into the MNE network. Hence, if strong intra-organisational linkages are a strategic objective for certain subsidiaries within the MNE network, then informal institutional friction is an effect that could to be taken into consideration. This might play a particularly pronounced role in the internal transfer of products and knowledge, which is most likely to involve a transaction across country borders (Yamin, 2004; Ambos \& Ambos, 2009).

Lastly, the proposed interaction term has been investigated in this study in order to shed some more light on the complexity that other institutional distance studies often ignore i.e. the relationship of formal and informal institutions as advocated by North (1990). The interaction term was significant for the intra-organisational relationships and autonomy models. That means that subsidiaries whose home countries are at a greater formal institutional distance do, in line with the expectations of this study, show higher levels of intra-organisational relationships. However, with greater informal institutional distance, the subsidiaries whose home countries are at a greater formal institutional distance show lower levels of intra-organisational relationships even if formal institutional distance is large. This indicates that concepts such as the 'liability of foreignness' are still a major factor for foreign-owned subsidiary development (Rugman et al., 2011), even in a developed country context as indicated in Yamin (2004).

For the autonomy models, this study suggests that informal institutional distance moderates the enabling effects of formal institutional distance when it comes to the decision-making autonomy granted to the subsidiary. In particular, in line with the expectations of this study, through the interaction terms, it has been indicated that subsidiaries located in countries at a greater formal institutional distance have more decision-making autonomy. Meanwhile, subsidiaries located at a greater informal institutional distance have less decision-making autonomy, which is in line with previous findings (e.g., Gaur \& Lu, 2007). This indicates that multinational corporations, in order to fully exploit formal institutional transaction cost differentials, might grant higher levels of autonomy to their subsidiaries. However, what has been so far overlooked in the literature is that this effect is impeded by larger informal institutional distance.

The interaction term might have important implications for the subsidiary strategy literature. In particular, Rugman and Verbeke (2001) and Rugman et al. (2011) argue that modern MNEs distribute their value-adding activities internationally in order to fully exploit location-specific advantages. The authors further state that those activities might be very finely sliced up, depending on the location-specific costs of carrying them out. Yamin (2004) takes this one step further and argues that, depending on the activities carried out in the subsidiary, the relationships between the subsidiary and the other affiliated units also diverge according to the varying transaction costs between home and host countries. This study suggests that such value-adding activities, and in particular their integration into the MNE network, are not only allocated in regard to the somewhat more transparent formal institutional differences. But it seems that, the more subtle informal institutional differences are likely to have a greater effect on their allocation. Indeed, the present study emphasises that the costs of institutional distance are more nuanced, and more pronounced, in an intra-organisational context than is commonly assumed in frameworks such as the transnational MNE (Bartlett \&Ghoshal,1989) or the metanational MNE (Doz, 2001).

The interaction term failed to become significant for the inter-organisational network relationship model. Taking the results as a whole, this indicates two things; firstly, that informal institutional distance impedes the development of links with external entities, as indicated in the direct associations between informal institutional distance and inter-organisational relationships. Secondly, formal institutional differences might be less relevant to the development of such linkages than previously thought. Taken together in the context of this study, that means that subsidiaries located in countries at a greater informal institutional distance seem not only to struggle to link into local networks, but to link into the internal network too. This double 'push' factor is often neglected in the conceptual literature such as in Rugman and Verbeke (2001). It seems that the subsidiary located in a 
country at a greater informal institutional distance is held at arms-length from internal as well as external network actors. The empirical literature has not yet investigated this phenomenon in a single comprehensive study from a new international economics (NIE) perspective.

\subsection{Implications and Future Research}

On the theoretical level, this study casts some doubts on the relevance of formal institutional differences for foreign-owned subsidiaries between home and host countries in a more stable institutional context. Formal institutional distance was only found to be significant through the interaction terms. This raises the question of how formal institutional differences in a stable context should be handled in future international business research. The relevance of such differences might be restricted to certain industrial clusters or subsidiaries with specific roles; however, for a wide range of subsidiaries, they appear to be less important. For developing economies, this finding might give rise to the question of what is going to happen when the most acute problems such as corruption are minimised. What kind of influence will they have on subsidiary development after a stable formal institutional setting has been developed? On the empirical level, whereas some authors emphasise the use of appropriate institutional measures for the right research question (Berry et al., 2010), the interaction of institutions is mostly neglected. This study shows that such interaction can provide interesting insights that go beyond moderating effects of the more commonly applied moderators such as age or firm internationalisation (e.g., Gaur \& Lu, 2007; Schwens et al., 2011). The policy implications seem to be that, even in a developed country context, the host country's regulatory incentives do actually have only very limited impact on the development of foreign-owned subsidiaries. The formal institutional variables showed only very weak association with any of the subsidiary characteristics. This research provides evidence, however, that for subsidiaries from informally institutionally close countries, changes in policy might indeed make a difference, at least in regard to intra-organisational relationships and to autonomy. The resulting recommendation then is that FDI should be more strongly attracted towards informally institutionally close host countries, if the host region considers such factors as important for regional development. On the other hand, a deeper integration of foreign-owned subsidiaries into the local economy is a task that may only be achieved through the development of industrial clusters, or other agglomeration economies.

For managers, this study implies that informal institutional differences still have considerable impact on subsidiary development. Overcoming this difficulty could be a trigger for the development of new FSAs. This appears necessary to fully utilise the potential of host locations, which in turn might generate new economies of scale and scope, but also sources of new knowledge.

\subsection{Limitations}

This study suffers from several common shortcomings. For example, this research is based on a census database of subsidiaries located in the Northwest of England (NWE); hence conclusions have to be drawn carefully. Nevertheless, previous studies showed that subsidiary characteristics, as well as their network relationships do not differ largely between the regions of the UK (Phelps et al., 2003). The data used in this study is cross-sectional in nature, which naturally provides problems with causality. Although special care has been taken to minimise this issue, this study relies heavily on theory in order to make informed guesses about the causality. Longitudinal data could be used to confirm the results of this study. Furthermore, as in Salomon and $\mathrm{Wu}$ (2012), this study did not include performance measures. The associations between institutional distance and performance could be assumed to be of importance, however. It would be expected for example that firms which take institutional distance into account show better performance than firm that do not.

\section{References}

Ambos, T. C., \& Ambos, B. R. (2009). The impact of distance on knowledge transfer effectiveness in multinational corporations. Journal of International Management, 15(1), 1-14. http://dx.doi.org/10.1016/j.intman.2008.02.002

Ambos, T. C., Ambos, B. R., \& Schlegelmilch, B. B. (2006). Learning from foreign subsidiaries: An empirical investigation of headquarters' benefits from reverse knowledge transfers. International Business Review, 15, 294-312. http://dx.doi.org/10.1016/j.ibusrev.2006.01.002

Bartlett, C., \& Ghoshal, S. (1989). Managing across borders: The transnational solution. Boston: Harvard Business School Press.

Berry, H., Guillen, M. F., \& Zhou, N. (2010). An institutional approach to cross-national Distance. Journal of International Business Studies, 41(9), 1460-1480. http://dx.doi.org/10.1057/jibs.2010.28

Birkinshaw, J., \& Hood, N. (2000). Characteristics of Foreign Subsidiaries in Industry Clusters. Journal of International Business Studies, 31, 141-154. http://dx.doi.org/10.1057/palgrave.jibs.8490893 
Birkinshaw, J., Hood, N., \& Jonsson, S. (1998). Building firm-specific advantages in multinational corporations: The role of subsidiary initiative. Strategic Management Journal, 19, 221-241. http://dx.doi.org/10.1002/(SICI)1097-0266(199803)19:3<221::AID-SMJ948>3.0.CO;2-P

Buckley, P. J. (2009). Internalisation thinking: From the multinational enterprise to the global factory. International Business Review, 18, 224-235. http://dx.doi.org/10.1016/j.ibusrev.2009.01.006

Buckley, P. J., \& Ghauri, P. N. (2004). Globalisation, economic geography and the strategy of multinational enterprises. Journal of International Business Studies, 35, 81-98. http://dx.doi.org/10.1057/palgrave.jibs.8400076

Buckley, P. J., \& Casson, M. (1976). The future of the multinational enterprise. London: Macmillan.

Caves, R. E. (2007). Multinational Enterprise and economic analysis (3rd ed.). Cambridge: Cambridge University Press. http://dx.doi.org/10.1017/CBO9780511619113

Chang, S., Van Witteloostuijn, A., \& Eden, L. (2010). From the Editors: Common method variance in international business research. Journal of International Business Studies, 41, 178-184. http://dx.doi.org/10.1057/jibs.2009.88

Dikova, D., \& Van Witteloostuijn, A. (2007). Foreign direct investment mode choice: entry and establishment modes in transition economies. Journal of International Business Studies, 38, 1013-1033. http://dx.doi.org/10.1057/palgrave.jibs. 8400297

Dillman, D. A. (2000). Mail and Internet Surveys: The Tailored Design Method. NewYork: Wiley \& Sons.

Dimitratos, P., Liouka, I., \& Young, S. (2009). Regional location of multinational corporation subsidiaries and economic development contribution: Evidence from the UK. Journal of World Business, 44, 180-191. http://dx.doi.org/10.1016/j.jwb.2008.05.007

Doz, Y. L. (2001). From Global to Metanational: How Companies Win in the Knowledge Economy. Harvard: Harvard Business School Press.

Dunning, J. H., \& Lundan, S. M. (2008). Multinational Enterprises and the Global Economy. Cheltenham, Edward Elgar.

Edwards, R., Ahmad, A., \& Moss, S. (2002). Subsidiary Autonomy: The Case of Multinational Subsidiaries in Malaysia. Journal of International Business Studies, 33(1), 183-191. http://dx.doi.org/10.1057/palgrave.jibs.8491011

Feinberg, S. E., \& Gupta, A. K. (2009). MNC subsidiaries and country risk: Internalization as a safeguard against weak external institutions. Academy of Management Journal, 52(2), 381-399. http://dx.doi.org/10.5465/AMJ.2009.37315470

Forsgren, M. (2004). The Use of Network Theory in MNC Research. In Pedersen, T., \& Mahnke, V. (Eds.), Knowledge Governance and the MNC (pp. 18-37). Palgrave McMillan, Hampshire.

Forsgren, M., Holm, U., \& Johanson, J. (2005). Managing the embedded multinational. Edward Elgar, Cheltenham. http://dx.doi.org/10.4337/9781845428051

Frost, T. S. (2001). The geographic sources of foreign subsidiaries' innovations. Strategic Management Journal, 22, 101-123. http://dx.doi.org/10.1002/1097-0266(200101)22:2<101::AID-SMJ155>3.0.CO;2-G

Frost, T., Birkinshaw, J., \& Ensign, P. (2002). Centers of excellence in multinational corporations. Strategic Management Journal, 23, 997-1018. http://dx.doi.org/10.1002/smj.273

Gatignon, H., \& Anderson, E. (1988). The multinational corporation's degree of control over foreign subsidiaries: an empirical test of a transaction cost explanation. Journal of Law, Economics and Organization, 4, 305-36.

Gaur, A. S., \& Lu, J. W. (2007). Ownership Strategies and Survival of Foreign Subsidiaries: Impacts of Institutional Distance and Experience. Journal of Management, 33(1), 84-110. http://dx.doi.org/10.1177/0149206306295203

Gaur, A. S., Delios, A., \& Singh, K. (2007). Institutional Environments, Staffing Strategies, and Subsidiary Performance. Journal of Management, 33(4), 611-636. http://dx.doi.org/10.1177/0149206307302551

Ghemawat, P. (2001). Distance Still Matters The Hard Reality of Global Expansion. Harvard Business Review, 79(8), 137-147.

Hair, J. F., Anderson, R. E., Tatham, R. L., \& Black, W. (1998). Multivariate data analysis with readings (5th ed.). London: Prentice-Hall. 
Henisz, W., \& Swaminathan, A. (2008). Institutions and international business. Journal of International Business Studies, 39, 537-539. http://dx.doi.org/10.1057/palgrave.jibs.8400381

Henisz, W., \& Williamson, O. E. (1999). Comparative economic organization-Within and between countries. Business and Politics, 1(3), 261-277. http://dx.doi.org/10.1515/bap.1999.1.3.261

Hennart, J. F. (1991). Control in Multinational Firms: The Role of Price and Hierarchy. Management International Review, 31(4), 71-96.

Inglehart, R., \& Welzel, C. (2010).Changing Mass Priorities: The Link between Modernization and Democracy. Perspectives on Politics, 8, 551-567. http://dx.doi.org/10.1017/S1537592710001258

Inglehart, R., Basanez, M., Diez-Medrano, J., Halman, L., \& Luijkx, R., (2004). Human Beliefs and Values: A Cross-cultural Sourcebook based on the 1999-2002. Values Surveys.

Jaccard, J., Turrisi, R., \& Wan, C. K. (1990). Interaction effects in multiple regression. London: Sage.

Kraatz, M. S., \& Zajac, E. J. (1996). Exploring the Limits of the New Institutionalism: The Causes and Consequences of Illegitimate Organizational Change. American Sociological Review, 61(5), 812-836. http://dx.doi.org/10.2307/2096455

Lane, C. (1997). The social regulation of inter-firm relations in Britain and Germany: market rules, legal norms and technical standards. Cambridge Journal of Economics, 21, 197-215. http://dx.doi.org/10.1093/oxfordjournals.cje.a013666

McDonald, F., Warhurst, S., \& Allen, M. (2008). Autonomy, Embeddedness, and the Performance of Foreign Owned Subsidiaries. The Multinational Business Review, 16(3), $73-92$. http://dx.doi.org/10.1108/1525383X200800014

Monteiro, L. F., Arvidsson, N., \& Birkinshaw, J. (2008). Knowledge flows within multinational corporations: explaining subsidiary isolation and its performance implications. Organization Science, 19(1), 90-107. http://dx.doi.org/10.1287/orsc.1070.0264

North, D. C. (1990). Institutions, institutional change and economic performance. Cambridge: Cambridge University Press. http://dx.doi.org/10.1017/CBO9780511808678

Nunnally, J. C. (1978). Psychometric Theory. London: McGraw-Hill.

Osterman, P. (1994). How common is workplace transformation and who adopts it? Industrial and Labor Relations Review, 47(2), 173-188.

Peng, M. W., \& Pleggenkuhle-Miles, E. G. (2009). Current debates in global strategy. International Journal of Management Reviews, 11(1), 51-68. http://dx.doi.org/10.1111/j.1468-2370.2008.00249.x

Peng, M. W., Wang, D. Y., \& Jiang, Y. (2008). An institution-based view of the international business strategy: a focus on emerging economies. Journal of International Business Studies, 39, 920-936. http://dx.doi.org/10.1057/palgrave.jibs.8400377

Phelps, N. A., Mackinnon, D., Stone, I., \& Braidford, P. (2003). Embedding the Multinationals? Institutions and the Development of Overseas Manufacturing Affiliates in Wales and North East England. Regional Studies, 37(1), 27-40. http://dx.doi.org/10.1080/0034340022000033385

Roth, K., \& O'Donnell, S. (1996). Foreign subsidiary compensation strategy: An agency theory perspective. Academy of Management Journal, 39, 678-703. http://dx.doi.org/10.2307/256659

Rugman, A. M. (2012). Does country matter? Multinational Business Review, 20(3), 1-5.

Rugman, A. M., Verbeke, A., \& Nguyen, Q. (2011). Fifty Years of International Business Theory and Beyond. Management International Review, 51(6), 755-786. http://dx.doi.org/10.1007/s11575-011-0102-3

Rugman, A. M., \& Verbeke, A. (2003). Extending the theory of the multinational enterprise: internalization and strategic management perspectives. Journal of International Business Studies, 34, 125-137. http://dx.doi.org/10.1057/palgrave.jibs.8400012

Rugman, A. M., \&Verbeke, A. (2001).Subsidiary-Specific Advantages in Multinational Enterprises. Strategic Management Journal, 22(3), 237-250. http://dx.doi.org/10.1002/smj.153

Salomon, R., \& Wu, Z. (2012). Institutional distance and local isomorphism strategy. Journal of International Business Studies, 43, 343-367. http://dx.doi.org/10.1057/jibs.2012.3

Schmid, S., \& Schurig, A. (2003). The development of critical capabilities in foreign subsidiaries: disentangling the role of the subsidiary's business network. International Business Review, 12(6), 755-782. http://dx.doi.org/10.1016/j.ibusrev.2003.05.001 
Schwens, C., Eiche, J., \& Kabst, R. (2011). The Moderating Impact of Informal Institutional Distance and Formal Institutional Risk on SME Entry Mode Choice. Journal of Management Studies, 48, 330-351.

Shenkar, O. (2001). Cultural distance revisited: towards a more rigorous conceptualization and measurement of cultural differences. Journal of International Business Studies, 32(3), 519-535. http://dx.doi.org/10.1057/palgrave.jibs.8490982

Slangen, A. H. L., \& Beugelsdijk, S. (2010). The impact of institutional hazards on foreign multinational activity: A contingency perspective. Journal of International Business Studies, 11, 980-995. http://dx.doi.org/10.1057/jibs.2010.1

Taggart, J. H., \& Taggart, J. M. (2004). Impact of national culture differences on MNC subsidiary management. In McDonald et al. (Eds.), The process of internationalization: strategic, cultural, and policy perspectives (pp. 121-134). Palgrave: Basingstoke.

Taggart, J., \& Hood, N. (1999). Determinants of autonomy in multinational corporation subsidiaries. European Management Journal, 17(2), 226-236. http://dx.doi.org/10.1016/S0263-2373(98)00081-4

Verbeke, A., \& Greidanus, N. S. (2009). The end of the opportunism vs. trust debate: Bounded reliability as a new envelope concept in research on MNE governance. Journal of International Business Studies, 40, 1471-1495. http://dx.doi.org/10.1057/jibs.2009.44

Verbeke, A., \& Yuan, W. (2005). Subsidiary Autonomous Activities in Multinational Enterprises: A Transaction Cost Perspective. Management International Review, 45(2), 31-52

Williams, D. (2003). Explaining employment changes in foreign manufacturing investment in the UK. International Business Review, 12(4), 479-497. http://dx.doi.org/10.1016/S0969-5931(03)00040-4

Williamson, O. E. (2000). The New Institutional Economics: Taking Stock, Looking Ahead. Journal of Economic Literature, 38, 595-613. http://dx.doi.org/10.1257/jel.38.3.595

World Economic Forum. (2011). Global Competitiveness Report (2010-2011). Geneva.

Yamin, M. (2004). Subsidiary business networks and opportunity development in multinational enterprises: A comparison of the influence of internal and external business networks. In Ghauri, P. et al. (Eds.), Managing Opportunity Development in Business Networks (pp.91-109). Palgrave: Basingstoke.

Yamin, M., \& Andersson, U. (2011). Subsidiary importance in the MNC: What role does internal embeddedness play? International Business Review, 20(2), 151-162. http://dx.doi.org/10.1016/j.ibusrev.2010.07.005

Yang, Z., Wang, X., \& Su, C. (2006). A review or research methodologies in international business. International Business Review, 15, 601-617. http://dx.doi.org/10.1016/j.ibusrev.2006.08.003

Zaheer, S., Schomaker, M., \& Nachum, L. (2012). Distance without direction: Restoring credibility to a much-loved construct. Journal of International Business Studies, 43, 18-27. http://dx.doi.org/10.1057/jibs.2011.43

\section{Copyrights}

Copyright for this article is retained by the author(s), with first publication rights granted to the journal.

This is an open-access article distributed under the terms and conditions of the Creative Commons Attribution license (http://creativecommons.org/licenses/by/3.0/). 